\title{
Redefining the Role of Universities in a Rapidly Changing Landscape
}

\author{
Datuk Abdul Rahim Hashim
}

Over the past few decades, the Malaysian higher education sector has experienced important reform, particularly guided by the Malaysia Education Blueprint for Higher Education 2015-2025 to stimulate continued excellence in the system. However, the dawn of 2020 has unfolded many challenges as COVID-19 rages across the globe bringing sudden paralysis to the whole world. Indeed, the pandemic has affected the world and greatly impacted our lives not only from a health perspective, but also from the political, economic, and social aspects. To date, universities in Malaysia have been closed for more than four months, although the Ministry of Higher Education has recently permitted postgraduate students undertaking full-time research programmes to return to the university should their research necessitate their physical presence in laboratories, workshops, design studios or to use specific equipment available only on campus. For other university students, online or virtual teaching and learning is set to continue until the end of this year, although identified groups of students will be allowed to return to the campus in stages.

Traditionally, universities are institutions of higher learning and research, with the general mission of disseminating and discovering new knowledge, as well as moulding holistic graduates. For the past millennium, the concept of teaching and learning (T\&L) and its delivery has not evolved much from the typical lecture-centric approach, even with the advent of technology. Although universities attempted to introduce blended learning in efforts to keep up with the times and stay up-to-date with the new (digital) generation of students, the uptake was slow as many lecturers still preferred to deliver their lectures in the traditional face-to-face manner. However, the COVID-19 pandemic has caused a sudden tectonic shift in the higher education paradigm, forcing rapid changes that we have never witnessed before within such a short time.

\section{A. R. Hashim ( $\varangle)$}

University of Malaya, Kuala Lumpur, Malaysia

e-mail: rahimhs@um.edu.my 
As we endeavour to seek a new normal amidst this chaos while remaining compliant with social distancing efforts, universities have implemented many innovative and creative initiatives to ensure minimal disruption to teaching and learning. Notably, one of the aspects which universities had to urgently resolve at the beginning of the crisis was how to go on with "business as usual", especially with one of its core activities - teaching and learning (T\&L). Amongst the immediate changes we have seen was the accelerated shift from classroom-based lectures to a variety of online platforms, the heightened pace of innovation in virtual learning, as well as adjustments to the delivery and assessment of T\&L. There was also an evident shift in linear and fixed outcome-driven T\&L to a more flexible, responsive, and agile one within a short period of time. The adoption of online learning by lecturers that had seen some resistance prior to this has now been fast-tracked in a massive way.

As educators begin to embrace online learning, though it may not have been by choice, they are now challenged with devising ways and means to address the pressing need to make T\&L not only suitable for remote learning but also to ensure that students are engaged with their lectures, albeit through a computer screen. To ensure that their teaching remains effective and accessible on a remote basis, they need to adapt to a new practice of teaching, upskill and equip themselves with digital skills for online learning, and adjust to the new, remote learning environment without the physical interactions on campus they are familiar with. At the same time, students now have to take more responsibility for their learning progress and be self-motivated to pursue knowledge. This requires a great amount of dedication and self-discipline from both lecturers and students.

With an avalanche of online learning and applications, universities are also able to widen their scope and open up their doors to those who previously did not have the chance to enrol in tertiary education due to personal limitations, be it to commit the time to attend lectures, or the financial means to relocate to a different state or country in pursuit of education. Microcredentialling, the latest buzzword in higher education that has gained more traction amidst the current crisis, will also unfold another vista to boost continuous learning, encouraging adults to reskill and upskill to enhance their career prospects, thus promoting life-long learning. Massive Open Online Courses (MOOCs) will, perhaps, also regain popularity in the education sphere as learning becomes more accessible to those whom it had not reached before. Universities will not be regarded as just tertiary institutions but life-long learning institutions.

There is also potential for greater collaboration between universities and industries, as well as amongst universities themselves to work together while opening up new avenues and modalities to provide a fresh take on delivering shared content and improving curricula. With an increasing number of courses being available online, lecturers can be encouraged to open up their classes to participation by students from partner universities for selected topics that are not available in the students' own university or in cases when there is no such expertise at their university. Students will also benefit from interactions with diverse peers from different institutions as well as gain more exposure through opportunities to learn from experts outside their university. At the same time, industries could play a larger role in academia by firstly, collaborating with universities to provide digital and infrastructural support to facil- 
itate the transition to online learning, followed by sharing valuable input based on practical experience in the field to help universities train a future-ready workforce. As more $T \& L$ and research activities transition into the virtual setting, there will also be more possibilities for collaboration between institutions in terms of sharing physical facilities to optimise operations and maximise the use of existing resources and infrastructure.

Advanced technology has played a vital role in easing the sudden shift to online teaching and has made it possible for lecturers to now replicate smaller classes and personalise learning through both synchronous and asynchronous lectures. This, in turn, encourages more interaction between the lecturer and student, which is a crucial element for learning to be effective. With knowledge readily available at their fingertips, students can now study at their own time, pace, and convenience, having ample time to reflect on lectures, as well as being able to communicate with lecturers directly to pose questions and discuss ideas. It comes as no surprise that since we began implementing remote-learning on a full-time scale, students are reportedly more participative in their virtual classes, and attendance rates have also increased. While active participation in face-to-face classes may have been daunting for some students who shy away from actively participating in discussions due to personal barriers or peer pressure, they are now more comfortable and confident within the online learning setting. However, it also cannot be denied that accessibility to online content is still a major obstacle for students living in remote areas or unconducive environments for studying. Much work still needs to be done to improve infrastructures to facilitate and provide support for these groups of students.

As we move into online and remote learning as the new convention for higher education, at lFieast for the foreseeable future, one might also ask whether universities and university campuses are still relevant. It must be recognised that with the many positive changes and experiences in terms of the shift to online and remote learning, universities still play an important role in developing and moulding graduates to be well-rounded. Along the lines of the Malaysia Education Blueprint, there needs to be a balance between both knowledge and skills (ilmu), as well as ethics and morality (akhlak). One cannot expect students to leave the university with a degree in hand, while deprived of the opportunity to experience the richness of face-to-face interactions with their lecturers and peers. Interpersonal skills and attributes such as being able to communicate effectively, teamwork, emotional intelligence (EQ), leadership, volunteerism, and other soft skills would be difficult and almost impossible to teach and experience in a purely online learning environment. It is on the campus grounds that they learn life lessons, interact with their professors and fellow students, participate in student activities, build relationships and network with others, all of which adds great value to their life during, and after university.

As we begin to envision and create a new normal for higher education, universities will face the challenge of finding the right balance in terms of how to blend online learning without forgetting the value of on-campus education. Online learning, with all its merits, is not the 'silver bullet' or a panacea to the crisis we are facing. Nevertheless, as the saying goes - in the midst of every crisis lies great opportunity. Life must, and should, go on. Although under difficult circumstances, this is the 
time for the higher education sector to revolutionise, particularly with the various technologies available to us today. Moving forward, what will the future be for universities, and where are we headed? Will universities still be relevant? It is safe to say that T\&L will undergo a revolutionary path with the current situation providing the impetus. What is certain is that universities have to work together as a global community to prepare students for an uncertain future while making every effort to ensure that the quality of their programmes remain of high standard and remain accessible to all those who seek knowledge and wisdom.

Datuk Abdul Rahim Hashim is currently the Vice-Chancellor of Universiti Malaya (UM). Prior to this appointment, he was the Vice-Chancellor of Universiti Teknologi PETRONAS. In October 2016, he was admitted as a William Pitt Fellow by the Pembroke College of Cambridge. He is the Past President of the International Gas Union (2009-2012), the Past President of the Malaysian Gas Association (2003-2015) and Past President of the Asia Pacific Natural Gas Vehicle Association (2003-2009).

Open Access This chapter is licensed under the terms of the Creative Commons Attribution 4.0 International License (http://creativecommons.org/licenses/by/4.0/), which permits use, sharing, adaptation, distribution and reproduction in any medium or format, as long as you give appropriate credit to the original author(s) and the source, provide a link to the Creative Commons license and indicate if changes were made.

The images or other third party material in this chapter are included in the chapter's Creative Commons license, unless indicated otherwise in a credit line to the material. If material is not included in the chapter's Creative Commons license and your intended use is not permitted by statutory regulation or exceeds the permitted use, you will need to obtain permission directly from the copyright holder. 